\title{
Theoretical Foundations of the New Industrialization of the Mining Region under Globalization
}

\author{
Ludmila Kusurgasheva ${ }^{1}$, Olga Nedospasova ${ }^{2}$, and Evgeny Zhernov ${ }^{1, *}$ \\ ${ }^{1}$ Department of Economics, Institute of Economics and Management, T.F. Gorbachev Kuzbass State \\ Technical University, 28 Vesennyaya Street, 650000 Kemerovo, Russia \\ ${ }^{2}$ Department of Economics, Institute of Social and Humanitarian Technologies, Tomsk Polytechnic \\ University, 30 Lenina Avenue, 634050 Tomsk, Russia
}

\begin{abstract}
This study is intended to establish theoretical foundations of the new industrialization of the mining region under the globalization. The urgency of the problem is due to a significant de-industrialization of many branches of the Russian economy as a result of the neoliberal macroeconomic paradigm in the years of radical market reforms. As a result, a number of Russian regions has formed the structure of industrial production, which is characteristic mainly for the countries of the raw materials periphery. The authors see the new industrialization (neoindustrialization) as a strategic tool for solving the problem. The trend that has formed in the Russian regional policy to transfer the responsibility for the economy modernization to the regional level has attached the special importance to regional studies. Exhaustion of predominantly raw-materials export model of economic growth has put Kuzbass, the mining region in Western Siberia, in the most difficult situation due to its tight dependence on the state of the world market of energy resources. This article presents a theoretical justification of the need, feasibility and advisability of neoindustrialization for the mining region in the conditions of globalization.
\end{abstract}

\section{Introduction}

The purpose of the study is to establish theoretical foundations of the new industrialization of the mining region as the key element of the Russian economy modernization in the conditions of globalization. The scientific novelty of the study is in the development of the concept of neo-industrialization of the Russian economy in relation to the resourceextracting regions and specific features of the present stage of their economic development determined by global trends. The scientific significance is in identification and systematization of the theoretical (conceptual) foundations of neo-industrialization of the mining region as illustrated by the Kemerovo region - an important mining region in Western Siberia.

\footnotetext{
* Corresponding author: zhee.eti@kuzstu.ru
} 
The practical significance of the study is related to the possibilities to use the proposed concept for justification, formulation and adoption of solutions on strategic issues of socioeconomic development of the resource-extracting subjects of the Russian Federation.

This goal is achieved by means of identification and scientific substantiation of the necessity, opportunity and feasibility of new industrialization of the resource extracting region, by the comprehensive analysis of the international experience in changing the socioeconomic role of this type of region in modern conditions.

The relationship of this study with the previously published works. The entire array of specialized literature, which seems important for the research topic, can be divided into three blocks. The first block consists of classical studies of foreign authors of the twentieth century on general problems of the regional economy and state regulation of socioeconomic development of regions including resource extracting ones. The second block includes the study of neo-industrialization as the strategic direction of economic development at present. In the third block, the issues related to the globalization of the economy are studied. To give the theoretical justification for the implementation of the mining region neo-industrialization, let us make a brief analytical review of classical theories and opinions of regionalist economists. This will reveal the basic theoretical principles for the development of the concept of the coal industry neo-industrialization as the impulse of neo-industrialization in the mining region. The appeal to the classical writings (theories) is justified, as they have become the basis of social and economic transformation of nowadays highly developed countries. These studies include the writings of I. Thünen, W. Launhardt, A. Weber, W. Christaller, A. Loesch, W. Alonso, W. Izard et al. Let us highlight the issues disclosed by them that are important for achieving the goal of our work.

Placing a single enterprise in relation to the basic factors of production in order to minimize costs has been reviewed in the work of Weber "Pure theory of industrial location" (1909), which is the development of the Standort theories of production placement by I. Thünen and Wilhelm Launhardt. Quite rightly for that time, A. Weber considered the costs of labor, raw materials, fuel resources, and costs of their transportation to each other as the traditional factors affecting the placement. A. Loesch outlined all the known theories of the location of production in the book "The spatial organization of the economy" (1940), he extended the theory of central places of W. Christaller and developed the theory of the organization of economic space. His provisions can be used to justify the "corridor of opportunities" of the spatial development of the Kemerovo region with an area of $4 \%$ of the territory of Western Siberia.

W. Izard tried to create an integrated model of territorial projections of socio-economic life of society in major works "Location and Space Economy" (1956) and "Methods of Regional Analysis" (1960). There, the economic landscape of the territory determines the combination of consumer demand, its geographical distribution and the availability of these or other economic resources. W. Izard was a supporter of the technical and economic approach, in which special emphasis was placed on the raw materials and the transport component of the cost of production and its exposure to the scale of production. This provision remains relevant in relation to the resource-extracting Kemerovo region (the region coincides with the greater part of the territory of Kuzbass - the Kuznetsk coal basin one of the largest coal deposits in the world; now the name of "Kuzbass" is the second title of the Kemerovo region) with its median geographic location in the country.

The new theory focuses not so much on the traditional factors of placement (transport, material and labor costs), but on the intangible factors - innovations. "The new combinations", or innovations, in the theory of economic dynamics of J. Schumpeter ("Theorie der wirtschaftlichen Entwicklung", 1911) include the development of new sources of raw materials. In the capitalist reality, according to the influential Austrian- 
American economist, the predominant importance lies in the competition based on the discovery of not only new technologies, but also new sources of raw materials. This competition ensures a significant cost reduction and (or) quality improvement. Therefore, in this study, we consider the innovative component as a factor in the distribution of productive forces crucial for neo industrialization of the raw material coal industry as the key sector of the Kemerovo region industry.

The theory of growth poles by F. Perroux ("Economic Space: Theory and Applications", 1950 [1]) has received wide recognition in the studies of regionalistics, thus allowing us to draw a conclusion about the importance of the sectoral structure of the regional economy and, above all, about the recognition of the leading role of industries creating new goods and services. The centres that host the operations of the leading industries become the poles of attraction of production factors, as they provide their most effective utilization. That is what leads to the concentration of enterprises and to the formation of economic growth poles, which enable to develop natural resources comprehensively, creating a technological chain of production together with modern infrastructure facilities.

For the Kemerovo region, it is also relevant to give a detailed presentation of the poles of economic growth by J.R. Lasuen ( "On Growth Poles", 1969 [2]): the growth pole can be represented by an integrated group of regional enterprises connected not only with the leading sector, but also with the export of the region. Export accounts for almost $95 \%$ of the Kuzbass foreign trade, and two-thirds of the export are the products of the fuel and energy complex, in which coal, in its turn, accounts for almost $70 \%$.

In regards to the Kemerovo region, to justify the need for dynamic development of the economy which is characteristic of neo-industrialization, for practical purposes experts offer to rely mainly on the theories of local growth and endogenous development. The latter are included as component parts in the concept of the regional self-development. The theory of innovations diffusion deserves no less attention, in their opinion. The model endogenous development is based on the maximum use of local resources: manpower; capital accumulated at the local level; entrepreneurial skills; specific knowledge of production processes. The availability of the network of production interactions between different sectors and within the production sectors (clustering), and the susceptibility of the regional economy to innovation make the basis of development. In this model, great attention is paid to various aspects of the development of the domestic regional market and to the solving of specific problems of the territory. However, that does not mean that the economy is of closed nature, although all activities are aimed primarily at creating conditions for the steady expansion of the use of local resources and, above all, labor. The approach means renouncing of the absolute character of the overall economic growth as the basis for development. In this context, the main task of the regional policy is to create conditions for the formation of local growth potential. Thus, the theory of local growth and the concept of endogenous development are organic elements of the concept of selfdevelopment in the region, according to which self-development mechanisms are built into the policies of the federal and regional authorities. This provision is consistent with the policy of neo-industrialization.

The second block of the literature includes the study of neo-industrialization as a strategic direction of economic development in modern conditions. The neoindustrialization concept in this context is actively developed by the following authors. A.P. Sussan and R.D. Kassira [3], in the first place, have made an assumption of leveling of the economy and social development as a result of re-industrialization, which is important for smoothing of the socio-economic inequalities of the Russian regions. Secondly, they have disclosed the changes in the essence of competition and the role of technologies. S.A. Aryeetey-Attoh, P.S. Lindquist, W.A. Muraco, and N. Reid [4] considered the problems of re-industrialization and emissions reduction in relation to each other, which is particularly 
important for environmentally problematic Kuzbass. A. Etzioni [5] drew attention to the social and psychological aspects of re-industrialization. R. Rothwell and W. Zegveld [6] outlined a wide range of problems in industrial development. Many authors explain the socalled "Asian miracle", the rapid growth of the economies of such countries as Korea and Taiwan, by the possibilities of transferring the human capital from developed to developing countries. This phenomenon is described in detail and determined as one of the locomotive growth factors in the work of A.B. Shifa [7]. In the case of Russia, and especially Siberia, a reverse negative trend is observed.

In the third block of the literature the problems associated with globalization of the economy were studied: M. Allais [8], P. Hawken, A. Lovins, H. Lovins [9], T. Piketty [10], et al. The impact of globalization on Kuzbass is due to the current dependence of the region on the state and trends of the global economy development. Thus, the complex current situation in the region's economy is largely associated with a reduction in coal prices at the world markets in the conditions of the global crisis.

The theoretical analysis has shown that in the current literature the state and development trends of a resource extracting region and the new industrialization of the economy are often considered separately, outside the context of globalization processes. Consequently, the problem of theoretical justification of new industrialization of the extracting region of Western Siberia in the conditions of globalization is relatively new in the economic science.

\section{Results and Discussion}

Western Siberia in general and the Kemerovo region, in particular, become particularly important for the neo-industrial turn of the Russian industry for the following reasons.

1. Kuzbass is an old industrial region with the established industrial structure and traditions, which is at the same time capable to start a new stage of industrial development. Natural climatic, orographic, landscape, cultural, and historical features of the Kemerovo region allow us to consider it following the accepted methodology as the region with the high recreational potential.

2. At present, the coal resource base of the country is concentrated on the territory of Kuzbass: this basin mines about $56 \%$ of bituminous coal and up to $80 \%$ of coking coal; earnings from coal sales are of great importance for the economy of Russia. Therefore, Kuzbass is prepared for the initial phase of the new industrial turn, provided technical and technological re-equipment of its industrial capacity and increase in production capacity of the processing sector. In the future, they can be used for the development of industrial clusters and technological centers in other regions of the country.

3. The special emphasis on new industrial development in Kuzbass is associated with the solution to stop the ongoing migration outflow from its territory.

The increasing share of knowledge-intensive and high-tech industries, the imbalance in the structure of training of highly qualified personnel and their involvement in the regional economy, low labor productivity in the coal industry in general and the high risks to the ecological safety of the region remain to be the problematic issues. That is why in Kuzbass accumulation of the indicators of the neo-industrial economy goes slower than in similar regions of the leading European countries, such as the Ruhr region in Germany. Its positive experience [11-13] demonstrates the need to intensify work in the field of import substitution and to stimulate high-tech products exports, especially in the framework of the clusters being formed. In this case, as the latest research of the experience of the regions of Europe shows [14], it is required to consider the dependence of the performance of innovative activity in the real sector of the economy on the quality of government control. 
The important goal of the neo-industrialization is to restore the Kuzbass economy as a reproductive integrity. This implies a gradual and consistent rejection of the practice of the organization of manufacture of individual products and support independent businesses, even related to the global technological networks. This is due to the fact that such companies tend to perform auxiliary and service functions with a minimal contribution to the creation and appropriation of the added value. This situation is natural, since global TNCs have been controlling for a long time all the main technological niches. Therefore, it is advisable to mining regions to participate in the creation of interconnected and integral production and processing chains within the Russian economic circuit. And only after the production is reorganized in this way, they can enter the world market. The more that Russia has the best compared with other countries variant of the formation of multi-link production and processing chains with the multiplying result in the form of increasing value-added capacity. Such a structural approach in the modern economic science is becoming more common and it is considered as one of the useful theoretical bases of the neo-industrialization policy [15].

Mining and deep processing of raw materials should be implemented on the basis of the new technology, which can be further used in the production of intermediate goods with high quality characteristics. This, for example, relates to chemical products developed in Kuzbass. In terms of economy modernization based on innovations, coal becomes primarily raw material for production of expensive chemical products. They are the necessary material for the deployment of a multi-processing industries. The latter, in turn, produce the necessary equipment for extractive industries and production of materials, etc.

In modern conditions, the models of regional development should be based on knowledge-intensive products, technologies, services, and current knowledge, which are not only strategically important resources, but also the equity. Therefore, regional growth poles should be based on educational and research centers, where all the innovative, scientific research, information and advisory, educational, and cultural activities are concentrated aimed at priority development of the region. This role in Kuzbass in the future should be performed by the innovative research and production center for development and implementation of new technologies in coal utilization - Kemerovo UgleNaukoGrad - a specialized division of the Siberian Branch of the Russian Academy of Sciences. It will deal with the development of fundamental and applied coal science in the country. Such centers in the peripheral regions are sources of knowledge for innovative firms [16]. In contemporary practice, the idea of growth poles is also realized in the creation of free and (or) special economic zones, territories of advanced socio-economic development, and industrial parks. It should be noted that the Kuzbass academic campus will be developed in close proximity to Technopark in the field of high technologies of the Kemerovo region which is the modern site for implementation of academic institutions studies. Creation of scientific institutions in the vicinity of the research object will contribute to the intellectual development of the region in the direction of neo industrialization, as well as to the transformation of the socio-cultural and educational spheres. Around the scientific center there should be highly specialized enterprises with small-scale and customized individualized production located using modern labor-saving technologies. These small and medium-sized firms are not only a guide for the formation of the modern industrial structure of the region, they also increase the region's innovation attracting new large research laboratories [17]. The experience gained in the implementation of this project can be used in other resource-extracting regions. This is how the authors see a possible way of revival of high-tech, economically and socially integrated system of regional economy.

The established theoretical foundations have allowed us to identify the following main areas for the implementation of the neo-industrialization of the mining region: 1) progressive changes in the structure of the regional industry; development of regional 
cluster structures; 2) growth of innovation and investment activities of resource extracting companies; 3 ) the greening of resource extracting production. The identified theoretical foundations of the neo-industrialization present the scientific basis of the specially developed conceptual approach to the justification of the necessity, possibility, and principal advisability of the new industrialization of resource extracting regions of the Russian Federation in the context of globalization. This is the main result of the work.

\section{Conclusion}

This work has defined the basic theoretical principles of transition to neo-industrial type of development of the regional economy, which, in our opinion, can be taken as the basis for justifying the neo-industrialization of a mining region. It is proved that the new industrialization of the leading coal mining complex in Western Siberia can and must become an impetus to accelerate the innovation development of the entire economic system of Russia. However, this is only the first step towards the structural modernization of the Russian economy. It is the government that must become the driving force behind the innovative type of modernization of the national economy in its main sectors and strategically important regions by conducting an active balanced industrial and regional socio-economic policy of the neo-industrialization.

\section{References}

1. F. Perroux, The Quarterly Journal of Economics, 64, 89 (1950)

2. J.R. Lasuen, Urban Studies, 6, 137 (1969)

3. A.P. Sussan, R.D. Kassira, The Re-industrialization Strategy in the Global Economy (2009)

4. S.A. Aryeetey-Attoh, P.S. Lindquist, W.A. Muraco, N. Reid, Northwestern Ohio: reindustrialization and emission reduction (Cambridge University Press, 2003)

5. A. Etzioni, Review of Policy Research, 2, 677 (1983)

6. R. Rothwell, W. Zegveld, Reindustrialization and Technology (1985)

7. A.B. Shifa, Essays on growth, political economy and development (2013)

8. M. Allais, La mondialisation: la destruction des emplois et de la croissance. L'évidence empirique (1999)

9. P. Hawken, A. Lovins, H. Lovins, Natural Capitalism: Creating the Next Industrial Revolution (1999)

10. T. Piketty, Le Capital au XXIe siècle (2013)

11. D.K. Carter (ed.), Remaking Post-Industrial Cities: Lessons from North America and Europe (2016)

12. Information Technik Nordrhein-Westfalen, https://www.it.nrw.de/index.html (2017)

13. Struktur und Entwicklung der sozialversicherungspflichtig Beschäftigten von 1980 bis 2004 (2006)

14. Rodriguez-Pose, M. Di Cataldo, Journal of Economic Geography, 15, 673 (2015)

15. J. Lin, New Structural Economics, A Framework for Rethinking Development and Policy (2012)

16. H. Pinto, M. Fernandez-Esquinas, E. Uyarra, Regional Studies, 49, 1873 (2015)

17. A. Agrawal, I. Cockburn, A. Galasso, A. Oettl, J. of Urban Economics, 81, 149 (2014) 